\title{
Studies on Process Standardization and Sensory Evaluation of Probiotic Chocolate
}

\author{
H.W. Deshpande ${ }^{1}$, V.T. Kharat ${ }^{1}$, S.D. Katke ${ }^{1 *}$ and V. B. Jadhav ${ }^{2}$ \\ ${ }^{1}$ Department of Food Microbiology and Safety, College of Food Technology, \\ VNMKV, Parbhani, India \\ ${ }^{2}$ Department of Agricultural Engineering, College of Agriculture, VNMKV, Parbhani, India \\ *Corresponding author
}

\begin{tabular}{|l|}
\hline K e y w o r d s \\
$\begin{array}{l}\text { Probiotic chocolate, } \\
\text { Microencapsulation, } \\
\text { viability, Lactobacillus } \\
\text { acidophilus, } \\
\text { Lactobacillus bulgaricus }\end{array}$ \\
\hline Article Info \\
\hline $\begin{array}{l}\text { Accepted: } \\
\text { 12 July } 2019 \\
\text { Available Online: } \\
\text { 10 August } 2019\end{array}$ \\
\hline
\end{tabular}

The popularity of chocolate around the world combined with high level of health related awareness of the contemporary consumer imposed the idea of enriching chocolate with probiotic bacterial strains. The main objective of this work was to obtain a potentially probiotic chocolate by using microencapsulated Lactobacillus strains. The Lactobacillus strains were encapsulated as micro-beads by using sodium alginate and guar gum and these beads were incorporated into chocolate suspension. This probiotic milk chocolate displayed the same sensory properties as the reference, probiotic-free chocolate. The number of live bacterial cells was maintained at the functional level of $10^{7}-10^{9} \mathrm{cfu} / \mathrm{g}$ after keeping for 4 weeks at $4^{\circ} \mathrm{C}$. Neither the texture nor the total and volatile acidity of chocolate masses were changed by addition of the microencapsulated Lactobacillus cells.

\section{Introduction}

Probiotic cells are defined as live microorganisms that, when administered in suitable amounts, confer a health benefit to the host. At present, probiotics are the driving force to design functional foods because they improve the properties of indigenous gut microflora and exert many positive effects on human health. The consumption of products supplemented with live cells of lactic acid bacteria (LAB), in particular with their probiotic strains, is believed to benefit consumers' health due to their well- documented positive impact on the function of gastro-intestinal tract and immune system, reduction of blood cholesterol, and apparent anticancer activity (Yoon et al., 2006). An increasing demand of consumers for foodstuffs supplemented with live LAB, preferentially probiotic ones, gave rise to studies on the enrichment of some other foods with these microorganisms. The development of new technologies facilitating the supplementation of confectionery with LAB can yield novel products, enriched with health-promoting ingredients that are capable of preventing civilization disorders. Because 
confectionery products are consumed by children and teenagers, their supplementation with live $\mathrm{LAB}$ is advisable.

Chocolate is a typically sweet, usually brown, food preparation of Theobroma cocoa seeds, roasted and ground, often flavoured, as with vanilla. It is made in the form of a liquid, paste, or in a block, or used as a flavouring ingredient in other foods. Chocolate possesses unique taste, flavour and texture and is also a source of biologically active substances, such as polyphenols, which display significant antioxidant properties and have a beneficial impact on human health, particularly on the cardiovascular system (Richelle et al., 2001; Schmitz, 2001). The incorporation of probiotics into chocolate could offer a good alternative to common dairy products and allow to broad the health claims of chocolate based food products. Indeed, recent market research into functional food has shown that, in relation to chocolate, digestive health was one of the most important drivers of consumer acceptance (Callebaut, 2009).

To be incorporated into food products and still maintain their viability and functionality, probiotic cells need to survive the adverse environmental conditions of the upper gastrointestinal tract and should be able to colonize the gut (Mattila Sandholm et al., 2002). Unfortunately, after cell ingestion, the number of live microorganisms reaching the gut is too low to exert their action, making cell protection necessary. Microencapsulation is the most promising technique applied to enhance bacteria viability. Microencapsulation can be defined as the process of entrapment/enclosure of microorganisms cells by means of coating them with proper hydrocolloid(s) in order to segregate the cells from the surrounding environment; in a way that results in appropriate cell release in the intestinal medium (Sultana et al., 2000; Krasaekoopt et al., 2003; Picot and Lacroix, 2003a). The various encapsulation techniques include extrusion, spray drying, spray cooling, lyophilisation, emulsion etc. Extrusion is the oldest and most common technique to produce capsules with hydrocolloids.

\section{Materials and Methods}

\section{Raw materials}

The raw materials such as Cocoa powder, skimmed milk powder, butter, sugar, lecithin etc. were procured from the local market.

\section{Preparation of starter culture}

The probiotic organism's viz. Lactobacillus acidophilus and Lactobacillus bulgaricus were individually grown in MRS broth at $37^{\circ} \mathrm{C}$ for 48h. The cultivated MRS broth was then centrifuged at 4,000rpm for $10 \mathrm{~min}$ to harvest the cells. The harvested cells were washed twice with sterile water. The biomass was taken as starter culture. The microencapsulation of probiotic bacteria was performed using the extrusion technique. Hydrocolloid solution was prepared by using a combination of sodium alginate and guar gum at $1 \& 0.8 \% \quad(\mathrm{w} / \mathrm{v})$ respectively. For preparation of $100 \mathrm{gm}$ probiotic chocolate, 10 $\mathrm{ml}$ of inoculum $(5 \mathrm{ml}$ each of L. acidophilus and L. bulgaricus) was mixed in $20 \mathrm{ml}$ of polymer solution. Probiotic cultures and polymer solution were mixed properly and passed through a syringe in the form of droplets into $0.3 \mathrm{M}$ calcium chloride solution. Interaction between the two solutions led to formation of beads $(2-5 \mathrm{~mm})$ and the resulting beads were then stored in $0.1 \%$ peptone solution at $4^{\circ} \mathrm{C}$.

\section{Processing technology for preparation of probiotic chocolate}

The major ingredient cocoa powder was mixed with skimmed milk powder. This cocoa 
powder and milk powder mixture was added into butter and gentle heating was carried out till it becomes smooth paste. Powdered sugar and emulsifier (lecithin) were added at this stage. Emulsifier helps to give smooth texture to chocolate.

Subsequently after heating, encapsulated probiotics were added to mixture and mixed well. Moulding was carried out to get chocolates with different shapes. These moulds were kept in a refrigerator or freezer for at least 6 hours. Finally, moulded chocolates were packed in wrappers.

\section{Proximate analysis}

All samples were analyzed for moisture, crude protein, crude fat, total ash and total carbohydrate contents according to their respective standard methods as described in (A.O.A.C., 2000).

\section{Sensory analysis}

The probiotic chocolate was evaluated for sensory characteristics like appearance, color, taste, flavor and overall acceptability post incubation period and also during storage at refrigerated conditions $\left(4^{\circ} \mathrm{C}\right)$.

Sensory evaluation was conducted in the laboratory by a panel of semi trained judges. Samples were scored based on a nine point hedonic scale. Judges were asked to rate the product on 9 point Hedonic scale with corresponding descriptive terms ranging from 9 'like extremely' to 'dislike extremely'.

\section{Statistical analysis}

The data obtained on various parameters were recorded and statistically analyzed by Completely Randomized Design (CRD) as per the method proposed by Panse and Sukhatme, 1967.

\section{Microbiological analysis}

To determine the viability of encapsulated probiotics in the chocolate, the enumeration was done at weekly intervals by releasing the entrapped strains from the microcapsules using the method suggested by Sheu and Marshall (1993).

\section{Results and Discussion}

\section{Chemical analysis of raw material}

The results pertaining to chemical analysis of raw materials are presented in Table 1. It was revealed from (Table 1) that, the moisture for cocoa powder $(6.72 \%)$, protein $(9.52 \%)$, crude fat $(12.60 \%)$, ash $(6.35 \%)$, crude fiber $(2.60 \%)$ and Carbohydrate $(62.21 \%)$. The results of the chemical analysis of the skimmed milk powder are moisture for skimmed milk powder $(3.2 \%)$, protein $(35.5 \%)$, crude fat $(1.0 \%)$, ash (8.4\%) and Carbohydrate $(51.78 \%)$.

These values of chemical properties recorded in the present study are similar to the values reported earlier by Ndife Joel et al., (2013) and Reference Manual for U.S. Milk Powders (2005).

\section{Chemical analysis of probiotic chocolate}

The data pertaining to various chemical properties of probiotic chocolate is depicted in Table 2. Data showed in table 2 revealed that the chocolate sample contained $5.64 \%$ moisture, $6.81 \%$ crude protein, $31.73 \%$ crude fat, $51.27 \%$ carbohydrates and $2.43 \%$ crude fiber. It was observed that the protein content of chocolate $(6.81 \%)$ was comparatively less than the protein content of cocoa powder $(8.50 \%)$ and skimmed milk powder $(35.5 \%)$. This may be as a result of the heating process which could have denatured some protein in the chocolate (Ndife Joel et al., 2013). 
Table.1 Chemical composition of raw material

\begin{tabular}{|l|c|c|c|c|c|c|}
\hline \multicolumn{1}{|c|}{ Raw Material } & $\begin{array}{c}\text { Moisture } \\
\text { \% }\end{array}$ & $\begin{array}{c}\text { Crude } \\
\text { Protein \% }\end{array}$ & $\begin{array}{c}\text { Crude Fat } \\
\text { \% }\end{array}$ & $\begin{array}{c}\text { Ash } \\
\text { \% }\end{array}$ & $\begin{array}{c}\text { Crude } \\
\text { Fiber } \\
\text { \% }\end{array}$ & $\begin{array}{c}\text { Total } \\
\text { Carbohydrates } \\
\text { \% }\end{array}$ \\
\hline Cocoa Powder & 6.72 & 9.52 & 12.60 & 6.35 & 2.60 & 62.21 \\
\hline $\begin{array}{l}\text { Skimmed Milk } \\
\text { Powder }\end{array}$ & 3.2 & 35.5 & 1.0 & 8.4 & - & 51.78 \\
\hline
\end{tabular}

Table.2 Chemical analysis of probiotic chocolate

\begin{tabular}{|l|c|}
\hline \multicolumn{1}{|c|}{ Parameter } & Values (\%) \\
\hline Moisture & $\mathbf{5 . 6 4}$ \\
\hline Crude fat & $\mathbf{3 1 . 7 3}$ \\
\hline Crude Protein & $\mathbf{6 . 8 1}$ \\
\hline Crude fiber & $\mathbf{2 . 4 3}$ \\
\hline Ash & $\mathbf{2 . 1 2}$ \\
\hline Carbohydrates & $\mathbf{5 1 . 2 7}$ \\
\hline
\end{tabular}

Table. 3 Viable counts (LAB) of probiotic chocolate during storage

\begin{tabular}{|c|c|}
\hline Time in Weeks & Viability (cfu/gm) of Probiotic LAB cultures \\
\hline $\mathbf{0}$ & $3.4 \times 10^{9}$ \\
\hline $\mathbf{1}$ & $3.7 \times 10^{9}$ \\
\hline $\mathbf{2}$ & $4.9 \times 10^{9}$ \\
\hline $\mathbf{3}$ & $2.8 \times 10^{9}$ \\
\hline $\mathbf{4}$ & $2.3 \times 10^{9}$ \\
\hline
\end{tabular}

Table.4 Physico-chemical properties of probiotic chocolate during storage

\begin{tabular}{|c|c|c|c|}
\hline $\begin{array}{c}\text { Storage } \\
\text { (in weeks) }\end{array}$ & $\mathbf{p H}$ & $\begin{array}{c}\text { Total acidity } \\
(\mathbf{\%})\end{array}$ & $\begin{array}{c}\text { Volatile acidity } \\
(\mathbf{\%})\end{array}$ \\
\hline $\mathbf{0}$ & 6.12 & 4.82 & 0.065 \\
\hline $\mathbf{1}$ & 6.09 & 4.85 & 0.071 \\
\hline $\mathbf{2}$ & 6.08 & 4.98 & 0.078 \\
\hline $\mathbf{3}$ & 6.03 & 5.02 & 0.086 \\
\hline $\mathbf{4}$ & 6.02 & 5.04 & 0.089 \\
\hline $\mathbf{S E} \pm$ & 0.0803 & 0.0094 & 0.0010 \\
\hline CD at 5\% & 0.2407 & 0.0294 & 0.0034 \\
\hline
\end{tabular}


Fig.1 Sensory evaluation of encapsulated probiotic chocolate samples using Hedonic Scale

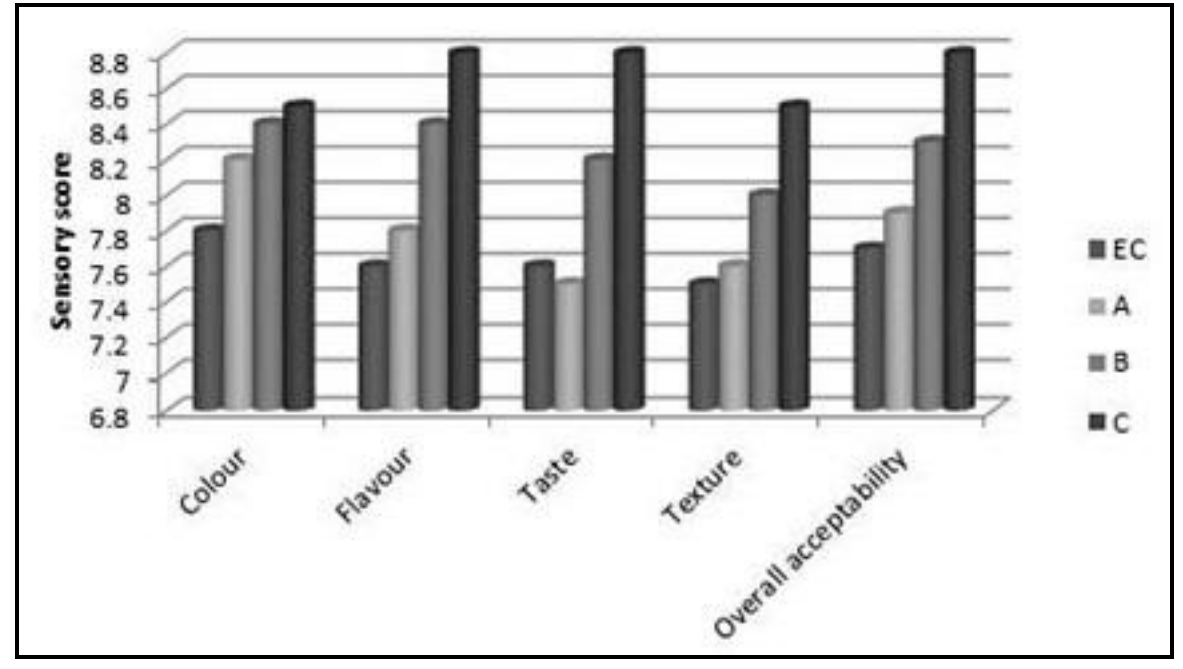

Flow Sheet.1 Preparation of starter culture

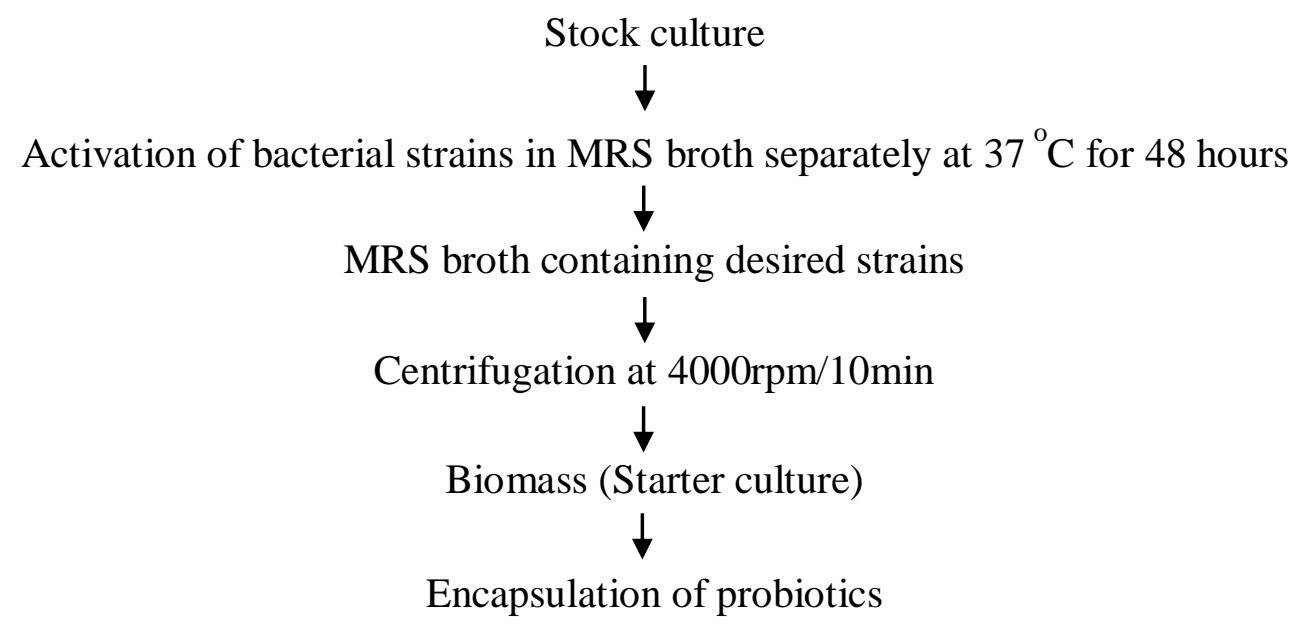

Flow Sheet.2 Microencapsulation of Strains

Preparation of polymer solution

Addition of probiotic cultures in the polymer solution

Extrusion of the cell-polymer solution into calcium chloride solution

Capsule formation by cross linking

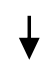

Recovery of capsules and storage in $0.1 \%$ peptone solution at $4^{\circ} \mathrm{C}$ 
Flow Sheet.3 Processing technology for probiotic chocolate

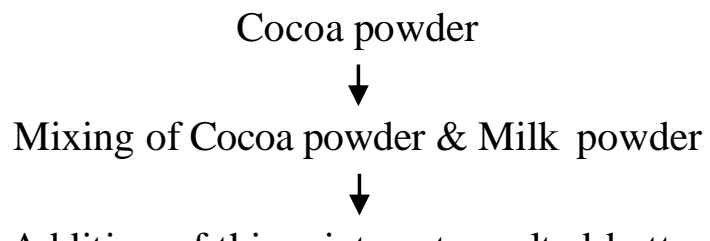

Addition of this mixture to melted butter

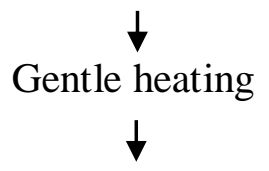

Addition of sugar and emulsifier (lecithin) to mixture

Smooth chocolate paste

Addition of encapsulated probiotics to this chocolate paste

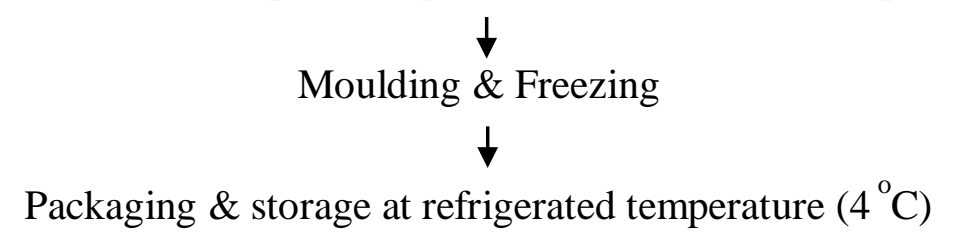

It was observed that the fat content of chocolate was much higher (31.73\%). The significant increase in the fat content of chocolate was as a result of the contribution of ingredients added in the production of chocolate such as butter, milk powder. Fats, especially the unsaturated fat are prone to oxidation and shorten shelf-life of food products (Borchers et al., 2000; Afoakwa et al., 2007). The ash content of probiotic chocolate was $2.12 \%$. Ash is an indication of mineral contents of foods and has been shown by Ieggli et al., (2011) to be high in cocoa products. Afoakwa et al., (2007) reported that chocolates are good sources of minerals, specifically calcium, magnesium, copper and iron.

\section{Sensory analysis of probiotic chocolate}

The organoleptic evaluation of four samples of probiotic chocolate was carried out. As per the score of hedonic scale sample $\mathrm{C}$ containing chocolate mass with encapsulated
$10 \%$ probiotic culture having $\left(10^{9}\right) \mathrm{cfu} / \mathrm{gm}$ had shown maximum consumer acceptability among all samples. The maximum score of chocolate in treated sample was obtained by sample C (i.e. 8.8). No significant differences were observed in attributes such as colour, taste, texture and flavour among all the four samples. Similar results have been reported by Nebesny et al., (2005) where sensory attributes of sucrose-free yoghurt-containing dark and milk chocolates and their yoghurtfree counterparts revealed excellent quality. The graphical representation of the sensory analysis depicted in Figure 1.

\section{Microbiological analysis of probiotic chocolate}

Viable counts (LAB) present in probiotic chocolate during storage

The viability of probiotics during storage is of paramount importance because for a probiotic food to confer health benefit the number of 
cells should be greater than $10^{7} \mathrm{cfu} / \mathrm{ml}$ or gm at the time of consumption. The results shown in Table 3 indicate that the number of probiotic bacteria's increased from an initial number of $3.4 \times 10^{9}$ to $4.9 \times 10^{9}$ during second week of storage. However, viable counts of probiotic bacteria are decreased after third and forth weeks of storage at 4ÚC. Although the viable count decreased, it was still above $10^{8} \mathrm{cfu} / \mathrm{ml}$ which is higher than the therapeutic minimum dose. Similar results are reported by Nebesny et al., (2005).

\section{Effect of storage period on physico- chemical properties of Probiotic Chocolate}

The prepared probiotic chocolate sample was further analyzed for physicochemical properties during storage up to 4 weeks. The data regarding the physicochemical properties of prepared probiotic chocolate sample are showed in Table 4.

The data (Table 4) revealed that the $\mathrm{pH}$ of accepted chocolate sample was found to be $6.12,6.09,6.08,6.03$ and 6.02 on the day of preparation, first week, second week, third week, and forth week after production respectively. It could be observed that the total acidity and volatile acidity of sample slightly increased during storage period. During storage period, the total acidity values of the chocolate sample significantly increased from $4.82(\mathrm{ml} 1 \mathrm{~mol} / \mathrm{l} \mathrm{NaOH}$ in 100 g) to $5.04(\mathrm{ml} 1 \mathrm{~mol} / \mathrm{l} \mathrm{NaOH}$ in $100 \mathrm{~g})$ from the day of preparation until the four weeks of storage. It could be observed that the volatile acidity of the prepared probiotic chocolate sample also slightly increased with the storage. The volatile acidity of fresh chocolate sample was 0.065 (g acetic acid/100g) whereas it was increased to 0.089 (g acetic acid $/ 100 \mathrm{~g}$ ) on $4^{\text {th }}$ week of storage. Data indicated that the storage time significantly affected the acidity level in the probiotic milk chocolate while the $\mathrm{pH}$ was decreased slightly. Adhikari et al., (2000) reported that microencapsulation of probiotics helps to fix and or improve the sensory properties of the final product. In general, sourness of fermented products (such as yogurt) produced by encapsulated starters is milder than those produced by un-encapsulated ones because of the lower amount of acid production and $\mathrm{pH}$ drop.

The trend to enrich new foodstuffs with live Lactobacillus cells is a novel and promising approach to the application of LAB in the food production. The supplementation of chocolate with encapsulated live LAB cells is one of these new applications. Thus in the light of the scientific data of the present investigation, it can be concluded that milk chocolate was a good carrier for Lactobacillus acidophilus and L. bulgaricus cells. The organoleptic evaluation during storage study suggests that the product can be kept for one month under refrigerated storage $\left(4^{\circ} \mathrm{C}\right)$ without deterioration in taste and flavor. Also considering the high viable cell count $(109 \mathrm{cfu} / \mathrm{ml})$ even after 4 weeks of storage. The process of preparation of probiotic chocolate can be techno-economically feasible, justifies the suitability of chocolate as a carrier for in microencapsulated mixture of probiotic Lactobacillus acidophilus and Lactobacillus bulgaricus. Chocolate is willingly consumed by children and teenagers. The supplementation of this product with encapsulated live probiotic cells can enrich their snacks.

\section{References}

A.O.A.C. 2000. Official methods of analysis, Association of Official Analytical Chemists. Washington DC.

Adhikari, K., Mustapha, A., Grun, I.U. and Fernando, L. 2000. Viability of microencapsulated bifidobacteria in set yogurt during refrigerated storage. 
J Dairy Sci., 83: 1946-1951.

Afoakwa, E. O., Paterson, A. and Fowler, M. 2007. Factors influencing rheological and textural qualities in chocolate - a review. Trends in Food Science \& Technology, 18; 290-298

Borchers, A. T., Keen, C. L., Hannum, S. M., and Gershwin, M. E. 2000. Cocoa and chocolate: composition, bioavailability, and health implications. Journal of Medicinal Foods, 3:77-103.

Callebaut.

B.

2009:

http://www.foodprocessingtechnology.c om/ contractors/ingredients/barrycallebaut/press 15. html (accessed Aug 9, 2014).

Ieggli, C., Bohrer, D., Nascimento, P. and Carvalho, L. 2011. Determination of sodium, potassium, calcium, magnesium, zinc and iron in emulsified chocolate samples by flame atomic absorption spectrometry. Food Chemistry, 124:1189-1193.

Krasaekoopt, W., Bhandari, B., and Deeth H. 2003. Evaluation of encapsulation techniques of probiotics for yoghurt. Int. Dairy J. 13, 3-13.

Matilla-Sandholm T, Myllarinen $P$, Crittenden R, Mogensen G, Fonden R, Saarela M 2002. Int Dairy J 12:173182.

Ndife Joel, Bolaji Pius, Atoyebi Deborah and Umezuruike Chris. 2013. American journal of food and nutrition, 3(1): 3138.

Nebesny E., Zyzelewicz D., Motyl I.,
Libudzisz Z. 2005: Properties of sucrose-free chocolates enriched with viable lactic acid bacteria. European Food Research and Technology, 220: 358-362.

Panse, V.S. and Sukhatme, P.V. Statistical Methods for Agricultural Workers. Indian Council of Agricultural Research, New Delhi.1967, 70-72.

Picot, A. and Lacroix, C. 2003a. Effect of micronization on viability and thermotolerance of probiotic freezedried cultures. Int Dairy J., 13: 455-462.

Reference Manual for U.S. Milk Powders. Arlington, VA: U.S. Dairy Export Council, 2005. P 41.

Richelle M, Tavazzi I, Oxford E 2001. J Agric Food Chem 49: 3438- 344220.

Schmitz H 2001 Chem Ind 12: 803-804.

Sheu, T.Y and Marshall, R.T. 1993. Microentrapment of Lactobacilli in Calcium Alginate Gels. Journal of Food Science, 54(3), pp 557-561.

Sultana K., Godward G., Reynolds N., Arumugaswamy R., Peiris P \& Kailasapathy K., 2000. Encapsulation of probiotic bacteria with alginate starch and evaluation of survival in simulated gastrointestinal conditions and in yoghurt. International journal of Food Microbiology. 62: 47-55.

Yoon K.Y., Woodams E.E., Hang Y.D. 2006. Production of probiotic cabbage juice by lactic acid bacteria. Bioresource Technology, 97: 1427-1430.

\section{How to cite this article:}

Deshpande, H.W., V.T. Kharat, S.D. Katke and Jadhav, V. B. 2019. Studies on Process Standardization and Sensory Evaluation of Probiotic Chocolate. Int.J.Curr.Microbiol.App.Sci. 8(08): 1527-1534. doi: https://doi.org/10.20546/ijcmas.2019.808.179 